\title{
Editorial: Technology Advances in the Utilization of Fossil Natural Gas as a Strategy in Transition to a Sustainable Energy System
}

\author{
Bamidele Victor Ayodele ${ }^{1 *}$, Samuel Asumadu Sarkodie ${ }^{2}$, Mathew Aneke ${ }^{3}$ and \\ Abul Quasem Al-Amin ${ }^{4}$
}

${ }^{1}$ Institute of Energy Policy and Research, Universiti Tenaga Nasional, Kajang, Malaysia, ${ }^{2}$ Nord University Business School (HHN), Bodø, Norway, ${ }^{3}$ Centre for Low Carbon and Sustainable Solutions, Sheffield, United Kingdom, ${ }^{4}$ Department of Geography and Environmental Management, University of Waterloo, Waterloo, ON, Canada

Keywords: natural gas, sustainable energy, $\mathrm{CO}_{2}$ emissions, low carbon economy, energy transition

Editorial on the Research Topic

Technology Advances in the Utilization of Fossil Natural Gas as a Strategy in Transition to a Sustainable Energy System

Natural gas as a fossil fuel has lower $\mathrm{CO}_{2}$ emissions from its combustion compared to other fossil fuels such as coal and oil. Hence, its demand has increased globally as a substitute for coal and oil-based fuel for power generation and transportation. The utilization of natural gas for transportation helps to mitigate the emission of other gaseous pollutants such as $\mathrm{SO}_{\mathrm{x}}$ and $\mathrm{NO}_{\mathrm{x}}$ as lesser amounts of these gases are emitted when combusted per kilometer. Besides being used as a low-carbon energy source, natural gas has been the main source of hydrogen production by catalytic steam reforming. The hydrogen produced can be utilized for fuel cell vehicles which has zero emissions and can significantly decarbonize the transportation sector. In addition to hydrogen, syngas, a mixture of hydrogen and carbon monoxide is an important chemical intermediate for producing methanol and Fischer-Tropsch liquids. This subject set was put together to pursue expert contributions on developments and advancements in the use of fossil natural gas for renewable energy processes due to the strategic position natural gas plays in decarbonizing the power and energy market as well as moving to a sustainable energy process.

Sustainable hydrogen production by solar-assisted natural gas thermal dissociation as a potential pathway for energy decarbonization was reported by Rodat and Abanades. A computation fluid dynamic technique was employed to model a windowless scalable solar reactor that could enable volumetric gas-phase methane cracking with possible hybridization. The process is expected to overcome the challenges of carbon deposition, continuous round-the-clock operation of the solar reactor with an intermittent energy resource, and technology scale-up. The interest in the production of natural gas from "shale" formation is gaining wide acceptance. He et al. reported the loss of shale gas during the coring process in the Eastern Sichuan Basin in China. The error reduction rate was employed to measure the shale gas loss to verify the simulated experimental method. The results showed that the error reduction rate had an improved performance compared to the United States Bureau of Mines (USBM) methods. Experts voiced their opinions on the need to optimize energy for sustainable development by setting an achievable target for carbon neutrality (Idowu et al.). One major constraint highlighted in the utilization of fossil fuel for sustainable energy processes is the 
emission of $\mathrm{CO}_{2}$. This challenge was addressed by Zubir et al. who analyzed the strategy for $\mathrm{CO}_{2}$ capture from the coal-fired power plant for dry reforming of natural gas. A significant $\mathrm{CO}_{2}$ emissions reduction was obtained using $\mathrm{CO}_{2}$ capture through calcium carbonate looping. Adeneye et al. established the link between carbon emissions, energy consumption, urbanization and economic growth in Asia using common correlated effects mean group estimator. The results necessitated the need for lawmakers to gain input into green energy policies and urban planning. Natural gas' importance as a primary alternative energy source in the move to a clean green energy system was also emphasized by Mohammad et al. The subject set had a cumulative view of 7,230 at the time of writing this Editorial, with 731 downloads of the various articles, demonstrating the interest in sustainable natural gas use.

\section{AUTHOR CONTRIBUTIONS}

All authors listed have made a substantial, direct, and intellectual contribution to the work and approved it for publication.

Conflict of Interest: The authors declare that the research was conducted in the absence of any commercial or financial relationships that could be construed as a potential conflict of interest.

Copyright (C) 2021 Ayodele, Sarkodie, Aneke and Al-Amin. This is an open-access article distributed under the terms of the Creative Commons Attribution License (CC $B Y)$. The use, distribution or reproduction in other forums is permitted, provided the original author(s) and the copyright owner(s) are credited and that the original publication in this journal is cited, in accordance with accepted academic practice. No use, distribution or reproduction is permitted which does not comply with these terms. 